\title{
POVRCHOVÝ PRŮZKUM SÍDLIŠTNÍHO A HOSPODÁŘSKÉHO KOMPLEXU TVRZE SUCHOTLESKY (K. Ú. RONOV NAD DOUBRAVOU)
}

\author{
JAN MUSIL - PETR NETOLICKÝ
}

Abstrakt: Založeni města Ronova nad Doubravou v roce 1307 vedlo k razantní proměně středověké sídelni sitě. Na dněsním katastru města se nachází pozůstatky tři zaniklých vsí Stusyně, Protivan/Protivenic a Suchotlesků. Suchotlesky ležicí v jihozápadní části katastru Ronova sestávají z vlastni zaniklé vsi, panského sídla (tvrze) s přidruženým hospodářským zázemím v podobě dvora a mlýna s minimálně třemi rybniky.

Klíčová slova: zaniklá středověká ves - tvrz - dvůr-mlýn - středověk - novověk - Čechy.

\section{Surface research into the settlement and economic complex of the Suchotlesky manor (Ronov nad Doubravou cadastral zone)}

Abstract: The establishment of the town of Ronov nad Doubravou in 1307 triggered radical changes in the local settlement structure. The area of the present-day town features the remains of three deserted villages: Stusyné, Protivany/Protivenice and Suchotlesky. Suchotlesky situated in the south-west section of the Ronov cadastral zone consists of a deserted village and a manor with affiliated hinterland in the form of a homestead and a mill with at least three ponds.

Key words: deserted medieval village - manor - homestead - mill - Middle Ages - modern age-Bohemia.

\section{1 Úvod}

V souvislosti s plněním dlouhodobého vědeckovýzkumného úkolu zaměřeného na poznání osídlení od pravěku po raný novověk na území okresu Chrudim se od roku 2008 výzkumu nemovitých kulturních památek systematicky věnuje Regionální muzeum v Chrudimi ve spolupráci s Katedrou archeologie Západočeské univerzity v Plzni. Navazujeme tím na poznatky získané především metodou povrchových sběrů prováděných v severní nížinaté části Chrudimska (Frolík-Sigl 1995) a v neposlední řadě také Ronovska (Malina 2011, 111-114; 2012, obr. 4). Souběžně probíhá výzkum zalesněných oblastí Železných hor a Žd’árských vrchů (srov. Musil 2007; 2011; 2011a; Musil-Netolický 2012; 2013; 2014; 2014a; 2014b; 2014c; 2015; 2015a; 2016; 2017; 2017a).

Okolí města Ronova nad Doubravou společně s majestátním hradem Lichnicí (něm. Lichtenburk) náleželo do někdejšího historického Čáslavska (obr. 1). V současnosti administrativně náleží okresu Chrudim. Relativně otevřená krajina Polabí se zde mírně vlní a postupně přechází v masiv Železných hor, které ve středověku tvořily přirozenou bariéru. V okolí města se nalézají dva samostatně stojící románské kostely, při nichž se nalézaly zaniklé středověké vsi Protivany/ Protivenice a Stusyně poblíž někdejšího brodu přes řeku Doubravu. Obě tyto vesnice předcházely vzniku Ronova nad Doubravou, který nechal založit Oldřich z Lichtenburku v roce 1307 (RBM IV, 824 č. 2124). Právě u osady Protivany s kostelem sv. Kř́iže se předpokládá existence někdejšího trhového místa. Trh byl pak společně s centrem farní správy přesunut do nově založeného městečka (Šimák 1938, 1221-1222). Obě osady ztrácely postupně na významu, ale definitivní tečku za jejich existencí učinily až události třicetileté války. Počátkům města Ronova nad Doubravou a jeho vztahu k zaniklým Protivanům/Protivenicím (k. ú. Ronov nad Doubravou; Profous 1951, 493; Roubík 1959, 107; Svoboda-Šmilauer 1960, 354; Smetánka 1987, 239; Pehal 2003, 3-17) a Stusyni (k. ú. Ronov nad Doubravou; Profous-Svoboda 1957, 226; Roubík 1959, 108; Svoboda-Šmilauer 1960, 354; Smetánka-Škabrada 1975, 262-266; 1977, 105-112; Smetánka 1987, 242) byla v minulosti věnována značná pozornost, zejména co se týče transformace středověké sídelní sítě (nejnověji - Malina 2011; 2012). 


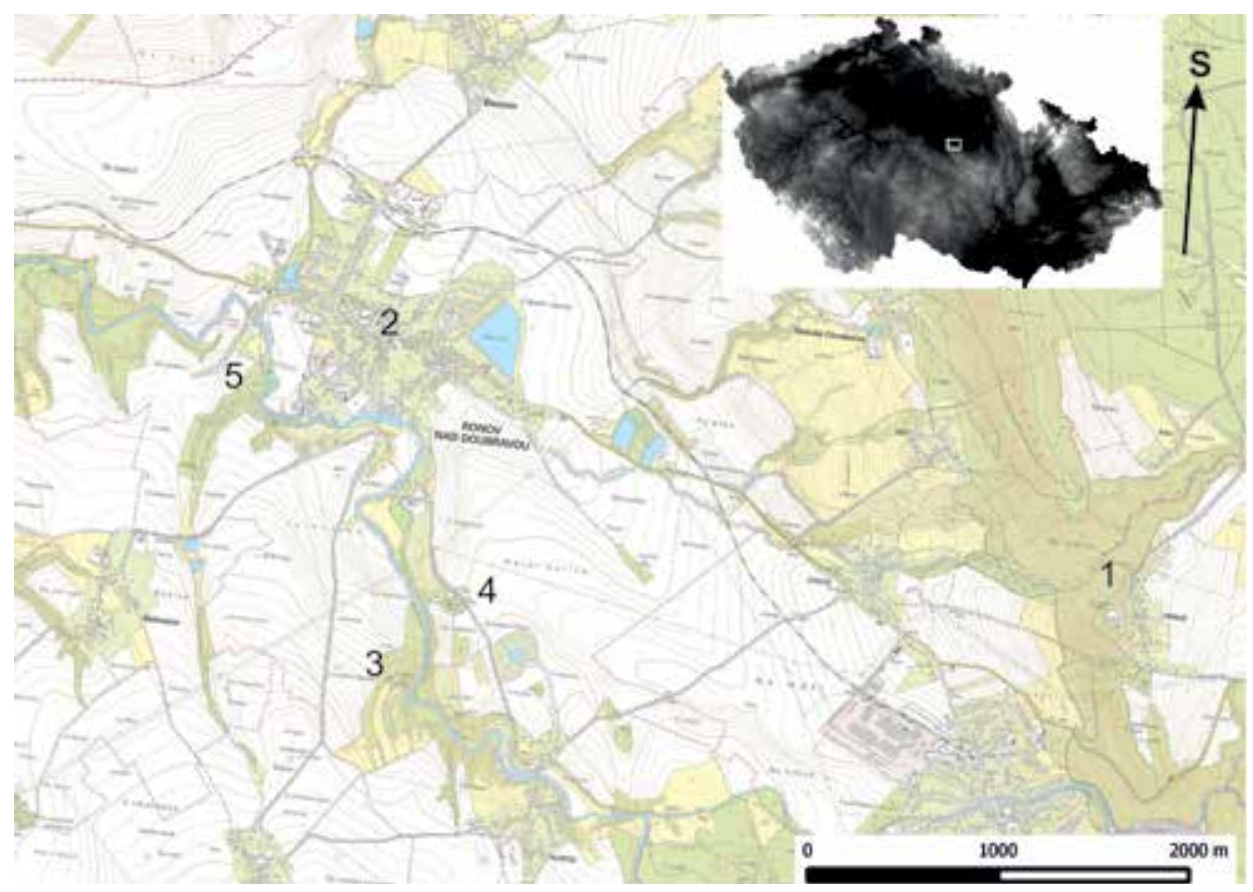

Obr. 1. Lokality zmiňované v textu. 1 - hrad Lichnice (k. ú. Podhradí v Železných horách); 2 - Ronov nad Doubravou; 3 ZSV Stusyně (k. ú. Ronov nad Doubravou); 4 - ZSV Protivany/Protivenice (k. ú. Ronov nad Doubravou); 5 - ZSV a tvrZ Suchotlesky (k. ú. Ronov nad Doubravou). Podkladová mapa Základní mapa ČR 1 : 10 000. Vytvořeno v programu QGIS. Zdroj ČÚZK.

Abb. 1. Im Text erwähnte Fundstellen. 1 - Burg Lichtenburg (Katastergebiet Podhradí im Eisengebirge); 2 - Ronov nad Doubravou; 3 - Mittelalterliche Dorfwüstung Stusyně (Katastergebiet Ronov nad Doubravou); 4 - Mittelalterliche Dorfwüstung Protivany/Protivenice (Katastergebiet Ronov nad Doubravou); 5 - Mittelalterliche Dorfwüstung und Feste Suchotlesky (Katastergebiet Ronov nad Doubravou). Kartenunterlage Grundkarte der Tschechischen Republik 1 : 10 000. Erstellt mit der Software QGIS. Quelle Tschechisches Amt für Landesvermessung und Kataster.

V jihozápadní části katastru města Ronova nad Doubravou se nalézají poněkud opomenuté relikty zaniklé středověké vsi Suchotlesky (obr. 2-4). Komplex sestává z vlastní zaniklé vsi, panského sídla (tvrze) s přidruženým hospodářským zázemím v podobě dvora a mlýna s minimálně třemi rybníky. Vesnice je známá zejména ze starší regionální literatury (Čermák 1882-1884, 238; Culek 1958, 47-52) a přehledových soupisových prací (Birnbaumová-Jansová 1929, 327-329; Roubík 1959, 108; Profous-Svoboda 1957, 234; Šulc 2001, 236). Více pozornosti bylo věnováno pozůstatkům tvrze (Sedláček 1900, 45-46). Poslední pokus představuje heslo v Encyklopedii českých tvrzi (Svoboda a kol. 2005, 778), v níž je publikován značně zkreslený plán ne zcela odpovídající situaci, navíc zde s tvrzí byly ztotožněny zbytky hospodářského dvora. Předložený př́ispěvek si klade za cíl tento dluh napravit.

\section{Metoda výzkumu}

Při výzkumu antropogenních reliktů na širším sledovaném území využíváme především takové nedestruktivní archeologické metody, které je možné provádět opakovaně a které přinášejí výchozí, podstatné a doplňující informace pro studium středověkého osídlení v převážně zalesněném prostředí Železných hor. Nejvhodnější metoda, kterou lze jednoduše aplikovat na vymezeném polygonu, je srovnání výstupů leteckého laserového skenování (dále LLS) a vizuálního nedestruktivního archeologického průzkumu s následným detailním geodetickým zaměřením 


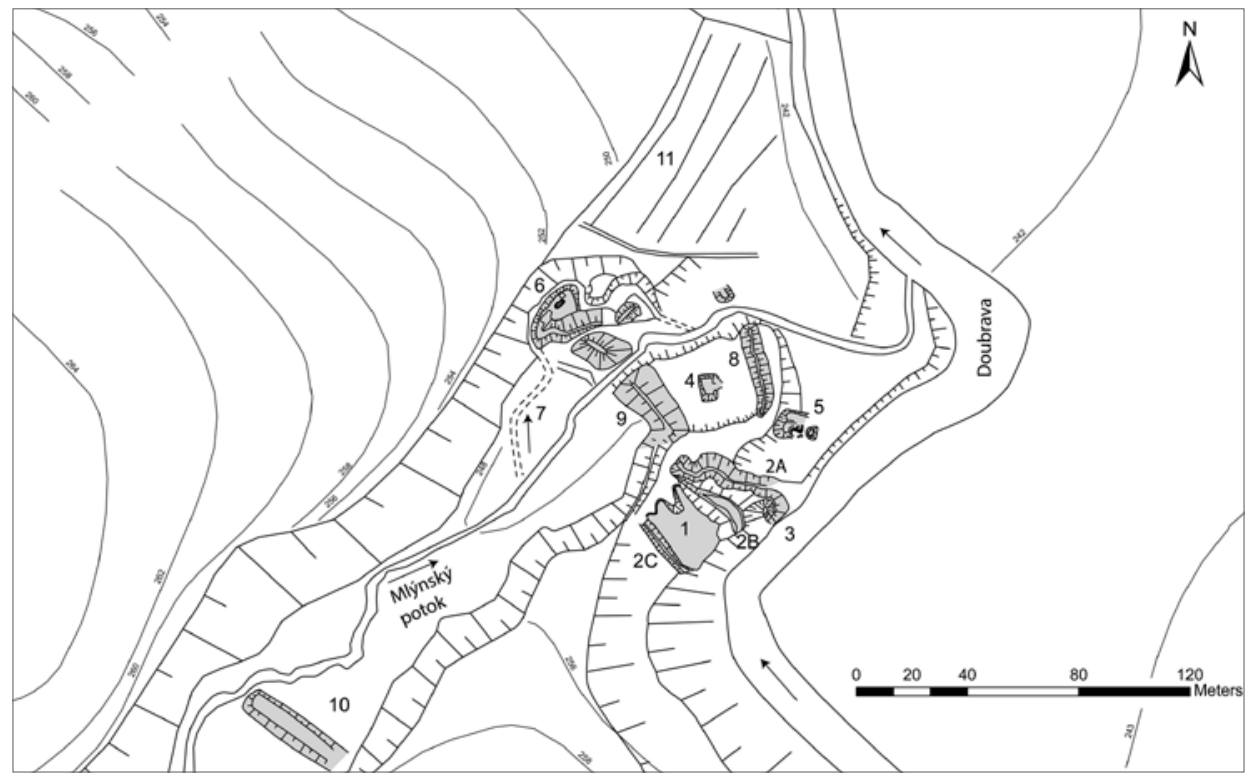

Obr. 2. Sídlištní a hospodářský komplex ZSV a tvrze Suchotlesky (k. ú. Ronov nad Doubravou). 1 - tvrz; 2A-2C - valy; 3 předsunutý objekt tvrze; 4 - hospodářský dvůr se zahloubeným centrálním objektem; 5 -zahloubený hospodářský objekt; 6 - relikty mlýna; 7 - náhon; 8 - val; 9 - val/hráz hospodářského dvora; 10 - hráz; 11 - relikty plužiny.

Abb. 2. Siedlungs- und Wirtschaftskomplex der mittelalterlichen Dorfwüstung und Feste Suchotlesky (Katastergebiet Ronov nad Doubravou). 1 - Feste; 2A-2C - Wälle; 3 - vorgezogenes Objekt der Feste; 4 - Wirtschaftshof mit eingetieftem zentralen Objekt; 5 - eingetieftes Wirtschaftsobjekt; 6 - Relikte einer Mühle; 7 - Mühlgraben; 8 - Wall; 9 - Wall/Damm des Wirtschaftshofes; 10 - Damm; 11 - Flurrelikte.

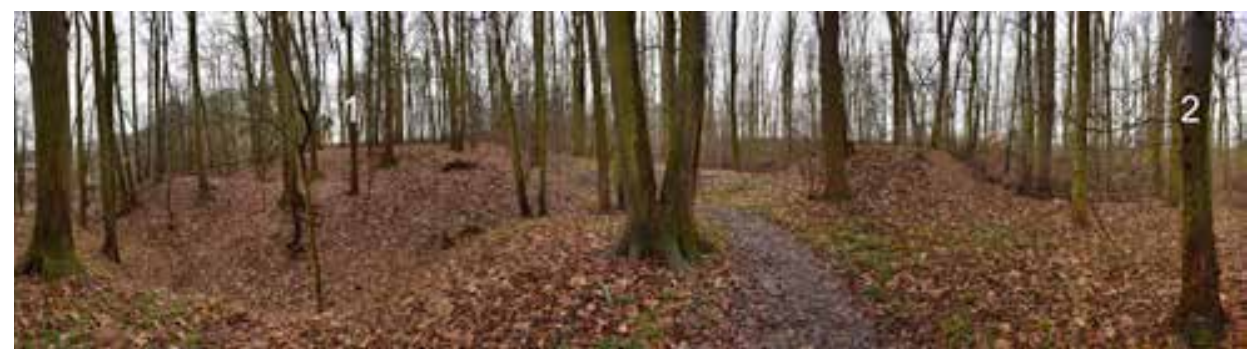

Obr. 3. Suchotlesky (k. ú. Ronov nad Doubravou). Panoramatický pohled od severu. Stav v roce 2017. 1 - vlastní tvrz; 2 dvůr. Foto O. Malina.

Abb. 3. Suchotlesky (Katastergebiet Ronov nad Doubravou). Panoramaansicht von Norden. Zustand im Jahr 2017. 1 eigentliche Feste; 2 - Hof. Foto O. Malina.

vybraných antropogenních reliktů pomocí totální měřičské stanice PENTAX V-227N a LEICA TS06plus 5" R500 přímo autory př́íspěvku. Pro sledované oblasti využíváme digitální modely reliéfu 5. generace (dále DMR5G) vytvořené metodou LLS (poskytuje Český úřad zeměměřický a katastrální). Kvalita zachycených, již interpretovaných archeologických reliktů na DMR5G není zcela vyhovující, ale větší rozměry jednotlivých antropogenních a přírodních reliktů je umožňují vcelku snadno lokalizovat, identifikovat a vizualizovat při použití programů, jako jsou např́iklad ArcMap10, RTV, SURFER nebo QGIS (srov. obr. 4). Dále jsou prováděny povrchové sběry, za určitých okolnosti doplněné o průzkum pomocí detektoru kovů. Průzkum pomocí detektoru kovů byl prováděn v roce 2007 a neposkytl žádné nálezy spadající do období stř̌edověku 


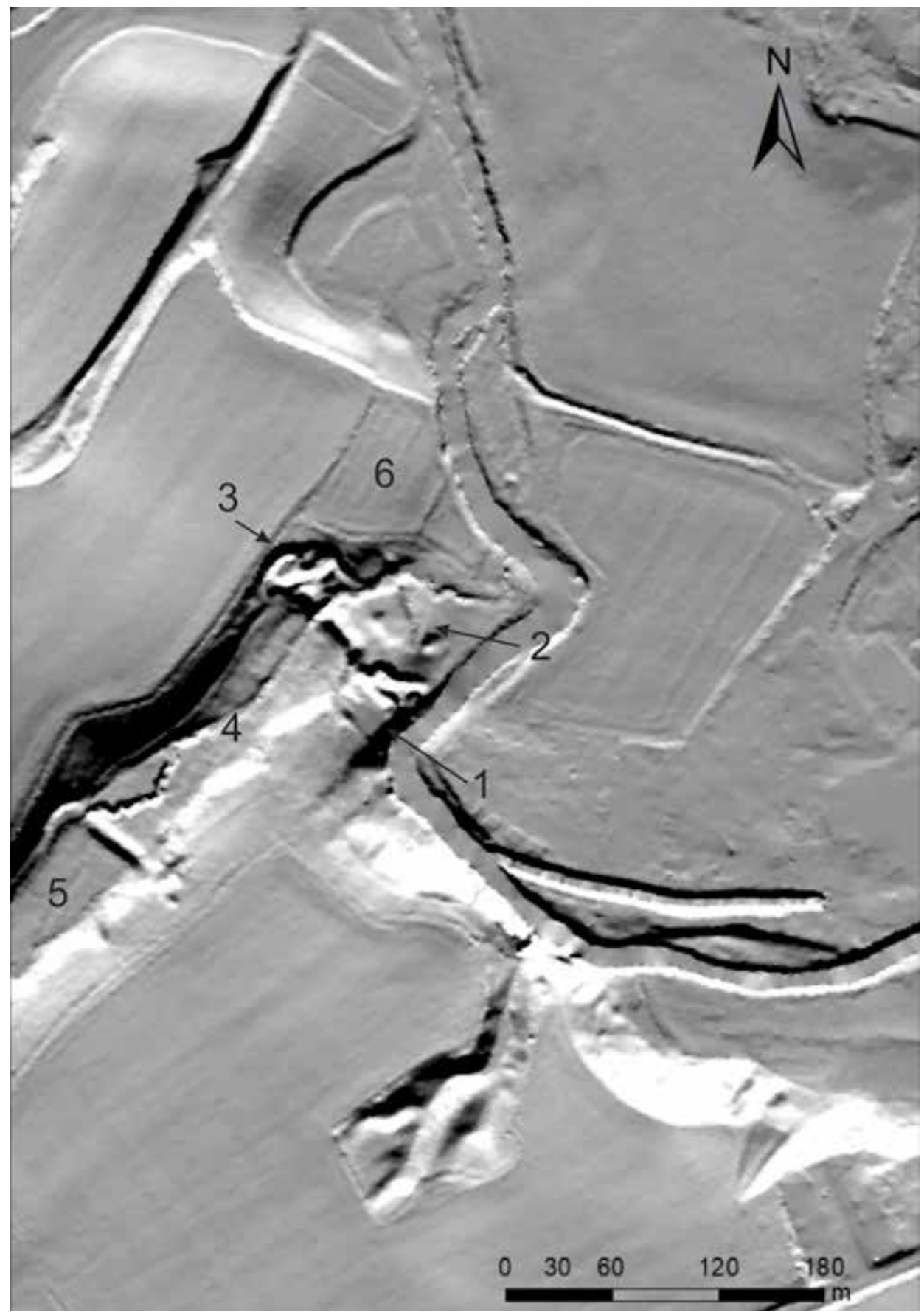

Obr. 4. Suchotlesky (k. ú. Ronov nad Doubravou). Digitální model reliéfu sídlištního komplexu. 1 - tvrz; 2 - dvůr; 3 - mlýn s náhonem; 4-5 - rybníky; 6 - plužina. Vizualizováno metodou Hillshading from multiple direction. Vytvořeno v programu RVT 1.3.

Abb. 4. Suchotlesky (Katastergebiet Ronov nad Doubravou). Digitales Reliefmodell des Siedlungskomplexes. 1 - Feste; 2 Hof; 3 - Mühle mit Mühlgraben; 4-5 - Teiche; 6 - Flur. Visualisiert mit der Methode Hillshading from multiple direction. Erstellt mit der Software RVT 1.3. 
či raného novověku. Povrchové sběry jsou aplikovány nejen v blízkosti antropogenních reliktů, ale i v širším okolí, zejména na polích (Smetánka 1977; Pehal 2003; Malina 2011, 111-114; 2012), v úvozech, ale i na březích částečně vypuštěných vodních nádrží (např. ZSV Ústupky - Musil 2007). Jejich souhrnné vyhodnocení je předmětem dalšího př́spěvku, který je věnován transformaci zdejší sídelní sítě. Kvantita a kvalita získaných souborů artefaktů a ekofaktů je vždy závislá na nejrůznějších faktorech na dané lokalitě (napřs. př́írodní podmínky - zalesnění, sklon reliéfu, podloží; časová délka osídlení a jeho intenzita atd.). Destruktivní archeologický výzkum je realizován pouze $\mathrm{v}$ př́ípadech, které byly vyvolány stavební aktivitou investora (např. hrad Rabštejnek - Baierl-Musil-Netolický 2015), což však není případ popisované lokality.

\section{Písemné prameny}

Ve středověku, v někdejším Čáslavsku, vedle sebe existovaly dvě vsi téhož jména, je tedy poměrně obtížné odlišit je v písemných pramenech od sebe. První zaniklá ves tohoto jména se nalézala na katastru obce Hraběšín (okr. Kutná Hora, Středočeský kraj) asi 13 km jihovýchodně od Kutné Hory a 9 km jihozápadně od Čáslavi. O její lokalizaci a roztřídění kusých písemných zmínek se zasloužil zejména Kliment Čermák (1882-1884, 238-239) a posléze i August Sedláček (1909, 848), na nějž navázali Antonín Profous a Jan Svoboda (1957, 234). S jistou dávkou pravděpodobnosti bychom mohli uvažovat o existenci Suchotlesk roku $1385,{ }^{1}$ kdy byla výslovně ves Suchotlesky provolána po smrti Ješka a Viléma ze Suchotlesk. Nárok obhajoval Vintír ze Suchotlesk, kterého zastupovali Diviš a posléze Ješek (Jan) z Chlumu (AČ XXXI, 233 č. 27). Na stížném listu z roku 1415 nalezneme Jana ze Suchotlesk, přičemž predikáty sousedících šlechticů umíst'ují tuto osobu právě do blízkosti Hraběšína (AČ III, 188). Další zmínka z roku 1417 se týká dělení majetku bratrů Jana, Viléma, Beneše a Diviše z Chlumu, přičemž Janovi z Chlumu připadly i Suchotlesky. Dle skladby majetku a řazení jednotlivých lokalit za sebou je zřejmé, že i v tomto případě se jednalo o Suchotlesky u Hraběšína (AČ III, 489-490). Nevíme ovšem, jak se Suchotlesky do držení rodu z Chlumu dostaly. S touto vsí lze jednoznačně spojovat údaj o držení vsi roku 1417 Janem z Chlumu (RT II, 132). Další osobou, se kterou je tato ves zmiňována, je Petr Janovský ze Suchotlesk a z Janovic, poprŕípadě jeho syn Bohuslav, který prodal roku 1487 vsi Paběnice, Petrovice, Třebonín, Újezd, Senetín a dvory v Suchotleskách a Hraběšíně Slavatovi z Košumberka (AČ V, 534; RT II, 433; srov. Čermák 1882-1884, 238-239). Bohuslav a Beneš ze Suchotlesk se v pramenech mihnou ještě roku 1505, kdy se účastnili tažení hotovosti proti Šlikům (AČ V, 320). Po smrti Bohuslava a po výše uvedené transakci nalézáme Suchotlesky v predikátu jeho vdovy Anny Miránkové ze Suchotlesk v letech 1523 a 1524 (AČ XXXII, 402; AČ XXXIII, 299). K roku 1533 jsou Suchotlesky u Hraběšína uváděny pouze jako pustý dvůr a z písemných pramenů mizí (srov. Sedláček 1900, 89; Profous-Svoboda 1957, 234).

Počátky tvrze a vsi Suchotlesky u Ronova nad Doubravou, které je věnován tento příspěvek, dostupné písemné prameny př́iliš neosvětlují. První spolehlivé zmínky pocházejí až z 16. století. Nutno předeslat, že dispozice zdejší tvrze poukazuje na středověké založení. Navíc musíme předpokládat poměrně značnou transformaci zdejší sídelní sítě v rámci založení města Ronova nad Doubravou v roce 1307. Nedomníváme se, že by ke vzniku vsi mohlo dojít až po tomto roce. Podle A. Sedláčka $(1909,848)$ náležely původně k majetku vilémovského kláštera, poté k lichtenburskému panství. Sedláček však v textu své tvrzení nijak nedokládá. Podíváme-li se na skladbu majetku vilémovského kláštera ve 13. a 14. století, zjistíme, že výše uvedené tvrzení má ale něco do sebe. Po celou dobu své existence se opati kláštera snažili scelovat majetkovou doménu do kompaktního celku. Dostávali se přitom do kontaktu s mocnými Lichtenburky, jejichž území statky kláštera rozdělovaly mocným klínem svých držav, a to nemluvíme o bojanovském újezdu v samém nitru Železných hor. Klášterní majetky, v nichž jsou výslovně

1 K tomuto závěru nás opravňuje dle našeho soudu držba rodu z Chlumu. František Roubík $(1959,108)$ písemné prameny pro obě popisované vsi sloučil dohromady pod Suchotlesky (u Ronova). Navíc u něho nalézáme chybné datum první písemné zmínky k roku 1358, nikoliv k roku 1385. Z Roubíkova $(1959,108)$ soupisu přejal toto chybné datum (navíc pro Suchotlesky u Hraběšína) i chrudimský archivář Ivo Šulc (2001, 236). Podobné promíchání písemných zmínek nalézáme i v dílech jiných autorů (Orth-Sládek 1870, 784; Sedláček 1900, 40, 42, 44-46, 89, 114). 
zmíněny např́íklad Zehuby či Mladotice, dosahovaly až k samotnému Ronovu nad Doubravou. Na základě etymologie bychom mohli uvažovat i o klášterní lokaci v prŕípadě Kněžic a Biskupic. Je pravděpodobné, že sama řeka Doubrava zde tvořila severovýchodní hranici klášterních držav, přičemž Suchotlesky, ačkoliv leží vzdušnou čarou $750 \mathrm{~m}$ jihozápadně od ronovského farního kostela sv. Vavřince, by ležely na západním, tj. klášterem drženém břehu řeky (k rekonstrukci klášterních držav srov. zejména Somer-Šrámek 2010, 16-38, Mapa 1). Další nepřímý důkaz někdejší klášterní držby bychom mohli spatřovat v držbě Trčků z Lípy. Statky vilémovského kláštera zničeného v roce 1421 při husitském tažení do východních Čech připadly dílem Janu Hertvíkovi z Rušinova a dílem Trčkům z Lípy (srov. Somer-Šrámek 2010, 41). Suchotlesky Trčkům náležely výslovně do roku 1557. Vlastní lichtenburské panství bylo prodáno za Viléma Trčky z Lípy roku 1555 poručníkům Albrechta a Václava Robmhápa ze Suché. Albrecht Robmháp se po dosažení zletilosti zmíněného roku 1555 chopil správy panství a k němu dokoupil roku 1557 od Viléma Trčky z Lípy vsi Kněžice, Biskupice, Suchotlesky a Mladotice, tj. evidentně díl, který byl k lichtenburskému panství připojen dodatečně. Suchotlesky roku 1582 sestávaly z usedlosti Jana Kmoška a Šimka Havlova, připojen k nim byl i grunt Ad. Matějíčka ve vsi Biskupicích. Ten roku 1614 vyhořel, načež se Matějíček společně se svou manželkou bez výhostu vytratil. Pozemky tohoto hospodářství byly připojeny k hospodářskému dvoru v Suchotleskách (Čermák 1882-1884, 238). Roku 1588 Albrecht Robmháp dává věnem své čtvrté manželce Anně Salavovně z Lípy vsi Kněžice, Biskupice, Suchotlesky a Mladotice; v držení je měla do konce svého života. Potvrzuje to i Albrechtova závět' z roku 1592. Po smrti Anny mělo její někdejší věno připadnout Janovi, Albrechtovu synovi, který ovšem umírá již roku 1595. Za jeho nezletilé syny Albrechta staršího a Václava se do roku 1614 o Suchotlesky stará Zikmund Robmháp (Sedláček 1900, 46). Roku 1615 se bratři rozdělili, Albrecht starší si ponechal Suchotlesky, zatímco Václav Moravany. Ačkoliv byl Albrecht starší nekatolík, při stavovském povstání na rozdíl od svých př́ibuzných zachoval věrnost císaři, a proto byl roku 1622 zproštěn obžaloby. V soupisu odvodů kontribuce pro Čáslavský kraj v roce 1622 je uvedeno, že Albrecht starší Robmháp ze Suché a na

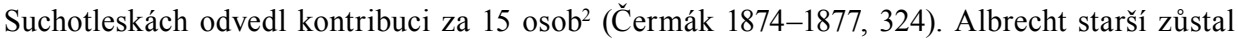
své víře věrný, a proto po obnoveném zřízení zemském roku 1627 emigroval. Suchotlesky koupil Jan Rudolf Trčka z Lípy, který je držel až do svého osudového pádu roku 1634 (Sedláček 1900, 45-46). Suchotlesky se tak v letech 1628-1636 staly součástí ledečského panství (srov. Sedláček 1900, 89, 114; 1909). V roce 1636 je zkonfiskován majetek Jana Rudolfa Trčky z Lípy. V soupisu je uváděna tvrz Suchotlesky s poplužním dvorem s 4,5 lány polí, 12 koňmi, 37 kusy hovězího dobytka a 180 ovcemi (Bílek 1883,688). Jedná se o poslední písemnou zmínku o existenci tvrze tohoto jména, sama ves zanikla v průběhu třicetileté války. Suchotlesky spolu s Bohdančí daroval císař roku 1636 Anně Kylmanové z Kylmanseku a ta je roku 1638 prodala Františku Chiesovi na Ronově (Sedláček 1900, 46). Dle soupisu poddaných podle víry z roku 1651 už existoval pouze hospodářský dvůr s devíti osobami - šafářem a jeho manželkou, šafářkou, třemi pluhaři a třemi špitálníky, děti do 9 let nebyly evidovány. K tomuto dvoru náležely nejen plužiny někdejší vsi Suchotlesky, ale byla k němu připojena i část plužiny zaniklé vsi Stusyně (Zahradníková-Šreinová 1999, 406, 419). Poslední zmínka o existenci už jen samostatného dvora pochází z roku 1727 (Čermák 1882-1884, 238).

Od počátku 17. století sledujeme postupnou ztrátu významu danou polohou v blízkosti městečka Ronova nad Doubravou. Již v roce 1582 z vesnice zbývaly pouhé dvě usedlosti. $\mathrm{K}$ vrchnostenskému dvoru byly připojovány pozemky zpustlých usedlostí z blízkého okolí. Definitivní tečkou byly události třicetileté války. Na přelomu let 1623 a 1624 zde kvartýrovaly jednotky pluku Julia Jindřicha, které si násilím od obyvatelstva vymáhaly další požitky. Nechvalně proslulý byl rytmistr Beneda (Líva 1951, 423, 532, 537, 545, 624). V roce 1624 na Ronovsku kvartýrovaly kompanie Collaltova regimentu (Líva 1951, 676). Císařská vojska regionem protáhla i v roce 1626 (Líva 1953, 186-187). V roce 1627 byla v Ronově kvartýrována osmá kompanie Collaltova regimentu (Líva 1953, 203, 217). Díky obnovenému zřízení zemskému sledujeme

2 Jedná se o 15 poplatníků, ke kterým je nutno připočíst další bliže neuvedené rodinné přislušníky. Z dokumentu bohužel nevyplývá, zda se jednalo pouze o obyvatele Suchotlesk. 
další vlnu emigrace z náboženských důvodů, a to včetně majitele panství. Kolem roku 1631 byl uložen u Ronova nad Doubravou mincovní depot, který byl objeven v roce 1845 (Nohejlová-Prátová 1957, 91). V roce 1634 se na Ronovsku nalézala část jízdního pluku S. Martiniho (Líva 1953, 321). V ř́ijnu roku 1646 se švédská jízdní jednotka pokusila zmocnit lstí nedalekého hradu Lichnice (Sedláček 1900, 42-43).

\section{Popis terénních pozůstatků}

\subsection{Tvrz (obr. 2:1; obr. 3)}

Jádro tvrze se nachází na terase mírného svahu sklánějícího se od jihozápadu k severovýchodu (obj. 1). Tvrziště je obdélného tvaru o rozměrech $26,4 \times 17 \mathrm{~m}$ (tj. horní hrany př́íkopu). $\mathrm{Na}$ terase se nedochovaly žádné stopy po reliktech zástavby. Nejlépe dochovaný relikt tvrziště představuje členitý př́ikop v jeho jihovýchodní části (obj. 2A). Jeho celková hloubka, počítaná od horní hrany jádra tvrze po dno, kolísá ve směru západ-východ od 3,5 do 6,4 m. Př́i vzniku př́ikopu bylo patrně využito částečně přírodního reliéfu. Ve členitém svahu byly identifikovány i zbytky menší terasy a val (obj. 2B). Zbytky po zasypaném př́íkopu byly zaznamenány i v jihozápadní části tvrziště, kde se dochovaly relikty o hloubce pouhých $0,5 \mathrm{~m}$ a maximální šířce $4 \mathrm{~m}$. V jihozápadní části se prŕíkop nedochoval vlivem povrchových úprav v nedávné minulosti, při parkové úpravě terénu. Severovýchodní část jádra tvrze chránil prudký svah a koryto řeky. Součástí tvrze byl i objekt situovaný na konci východní části prŕíkopu (obj. 3). Objekt byl identifikován na základě vystupujících reliktů ze stěn př́íkopu a prohlubně o rozměrech zasypaného dna 2,8 × 1,3 m. Rozdíl mezi výškou dna a korunou dochovaného objektu činí až 1,4 m. Objekt měl původně patrně půdorys čtverce a přístup do objektu mohl být ze shora v místě menší terasy (obj. 2B).

\subsection{Val (obr. 2:8)}

Jediným dochovaným reliktem oddělujícím vlastní tvrziště a předpolí je patrně sypaný val (obj. 8), který mohl zároveň sloužit i jako hráz. Maximální dochovaná výška a šiřka valu činí $1,2 \mathrm{~m}$ a $8 \mathrm{~m}$. Oba konce valu se nedochovaly v intaktní podobě.

\subsection{Hospodářské stavby}

V těsné blízkosti tvrziště se nachází ohrazený pravidelný prostor s centrální zahloubenou částí (obj. 4 -obr. 2:4, obr. 5). Tento relikt je umístěn zcela uprostřed terasy vymezené na západní straně relikty valu (obj. 9) a na východě valem (obj. 8). Objekt 4 je orientován svou delší stranou ve směru sever-jih. Vnější rozměry objektu činí $9,8 \times 6,8 \mathrm{~m}$ a dna $6 \times 4 \mathrm{~m}$. Hloubka měřená od horní hrany kolísá mezi 1,3 a 0,2 m. Do objektu ve východní části objektu směřuje nevýrazná konkávní linie, kterou můžeme interpretovat jako vstupní šíji do zaniklé zahloubené stavby.

Druhý objekt nepravidelného tvaru (obj. 5 - obr. 2:5, obr. 6) je zapuštěn svou západní stranou vně do strmého svahu v těsné blízkosti valu (obj. 8). Východní část objektu přechází do plochy terasy. Celkové rozměry objektu nelze zcela spolehlivě určit, zejména na východní straně je hranice objektu rozplizlá. V severovýchodní části objektu se zachovaly doklady kamenného zdiva.

Relikty třetího objektu jsou umístěny v těsné blízkosti hráze/valu (obj. 9) v severozápadní části předpolí tvrze (obj. 6 - obr. 2:6). Relikty stavby se nacházejí na uměle vytvořené terásce nepravidelného tvaru o rozměrech minimálně $10,5 \times 8,5 \mathrm{~m}$ s delší stranou orientace jihozápadseverovýchod. Terasa je částečně zasypána rozpadajícím se valem. Na terase byly identifikovány patrně zbytky zdiva a cihel v pravidelném čtvercovém uspořádání (obr. 7). Kolem severozápadní a severojižní části objektu je umístěn náhon (obj. 7 - obr. 2:7), který patrně ústil do potoka z výše umístěné kaskády rybníků. Objekt můžeme interpretovat jako zaniklý mlýn.

Severně od těchto reliktů se dochovaly nevýrazné pozůstatky po plužině v podobě nízkých terásek a pěti částečně dochovaných mezních pásů (obj. 11 - obr. 2:7, obr. 4). 


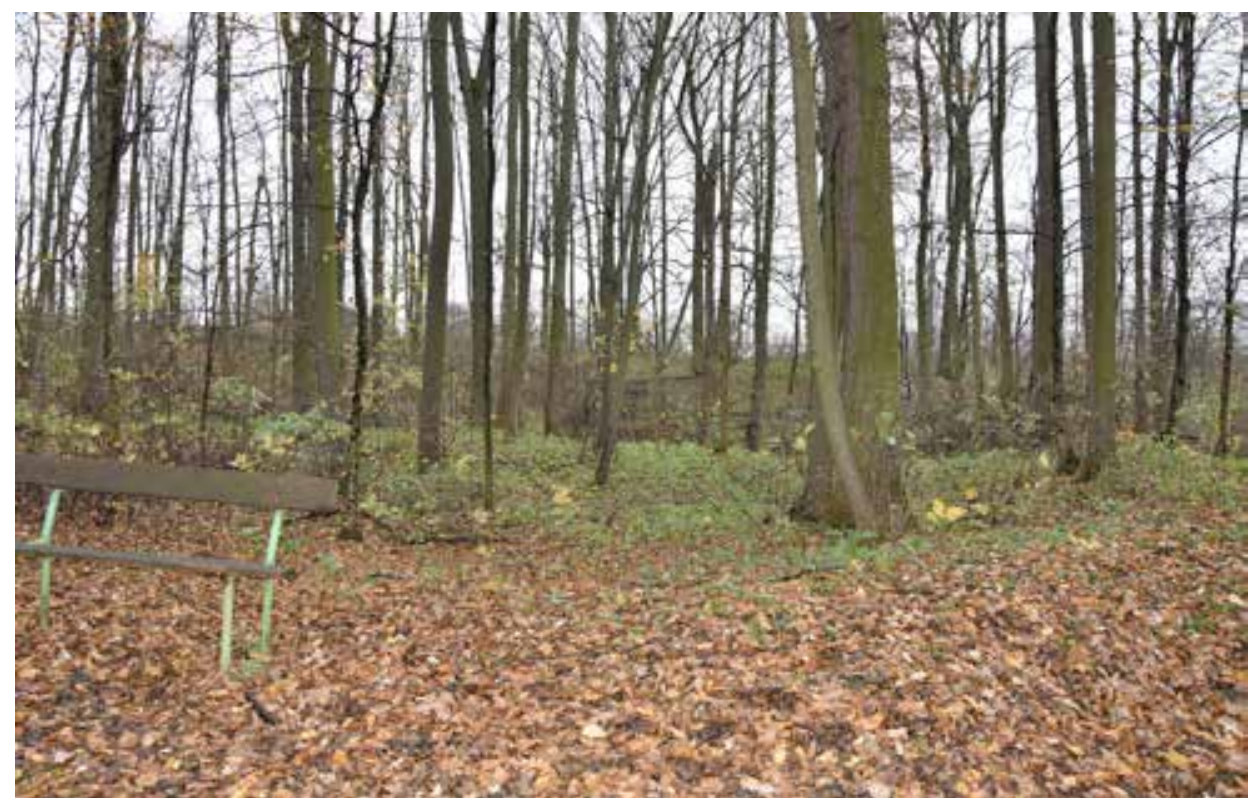

Obr. 5. Suchotlesky (k. ú. Ronov nad Doubravou). Hospodářský dvůr s centrálním zahloubeným objektem (obj. 4). Pohled od jihovýchodu. Stav v roce 2017. Foto J. Musil.

Abb. 5. Suchotlesky (Katastergebiet Ronov nad Doubravou). Wirtschaftshof mit zentralem eingetieften Objekt (Obj. 4). Blick von Südosten. Zustand im Jahr 2017. Foto J. Musil.

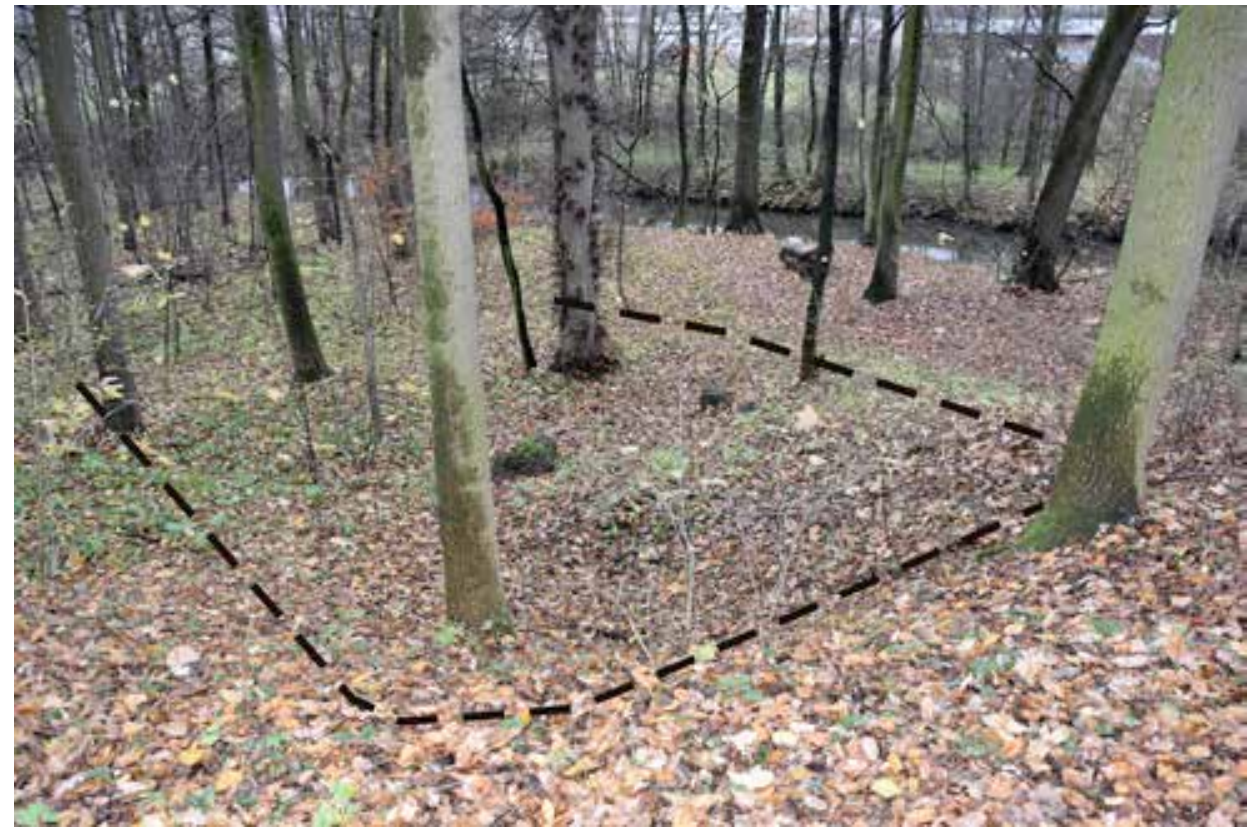

Obr. 6. Suchotlesky (k. ú. Ronov nad Doubravou). Relikty nejmladší zástavby - obj. 5. Pohled od západu. Stav v roce 2017. Foto J. Musil.

Abb. 6. Suchotlesky (Katastergebiet Ronov nad Doubravou). Relikte der jüngsten Bebauung - Obj. 5. Blick von Westen. Zustand im Jahr 2017. Foto J. Musil. 


\subsection{Hráze a rybniky}

Nejviditelnějším a nejzachovalejším objektem je hráz, která je umístěná nejblíže k vlastní tvrzi (obj. 9 - obr. 2:9). Jedná se o liniový konvexní objekt, který je orientován ve směru severozápad-jihovýchod. Celková délka objektu, včetně dvou přerušených úseků, je $67 \mathrm{~m}$. Maximální výška hráze je v současnosti 3,6 m a šiřka báze $13 \mathrm{~m}$. Ve vzdálenosti $160 \mathrm{~m}$ jihozápadním směrem od první hráze se nachází druhá menší hráz (obj. 10 - obr. 2:10). Přibližná plocha první záchytné nádrže činí zhruba $5800 \mathrm{~m}^{2}$. Ostatní hráze jsou v terénu velmi špatně čitelné.

\section{Interpretace terénní situace}

Informace získané nedestruktivním archeologickým výzkumem poskytly nová data potřebná $\mathrm{k}$ porovnání prostorových dispozic s jinými tvrzemi v nejbližším okolí zkoumaného mikroregionu Ronov nad Doubravou v rámci mapování středověkého a raně novověkého osídlení Železných hor. Na začátek je třeba poznamenat, že při detektorovém průzkumu v roce 2007 a intenzivním povrchovém průzkumu prováděném v letech 2016-2018 nebyly z prostoru tvrze získány žádné movité archeologické nálezy. Datování se opírá o komparaci písemných pramenů a analýzu dispozice popisovaných antropogenních reliktů.

V rámci zpracování geodeticko-topografických dat, LLS a povrchového průzkumu byly definovány tři koncentrace antropogenních reliktů. První koncentrace zaujímající ústřední jádro tvrze a př́kop je umístěna na skalním výběžku v nadmořské výšce $251-250 \mathrm{~m} \mathrm{n}$. m. (obr. 3). Samotná tvrz byla chráněna na východní straně strmým svahem a vodním tokem, na západní straně vytvořenou vodní nádrží a na severu příkopem a menším valem. Fortifikace mohla být doplněna i o vysunutou věžovitou stavbu čtvercového půdorysu umístěnou u brodu přes řeku Doubravu (obj. 3 - obr. 2:3). Nejhůře dochovaným místem je jižní strana tvrziště, na které dnes

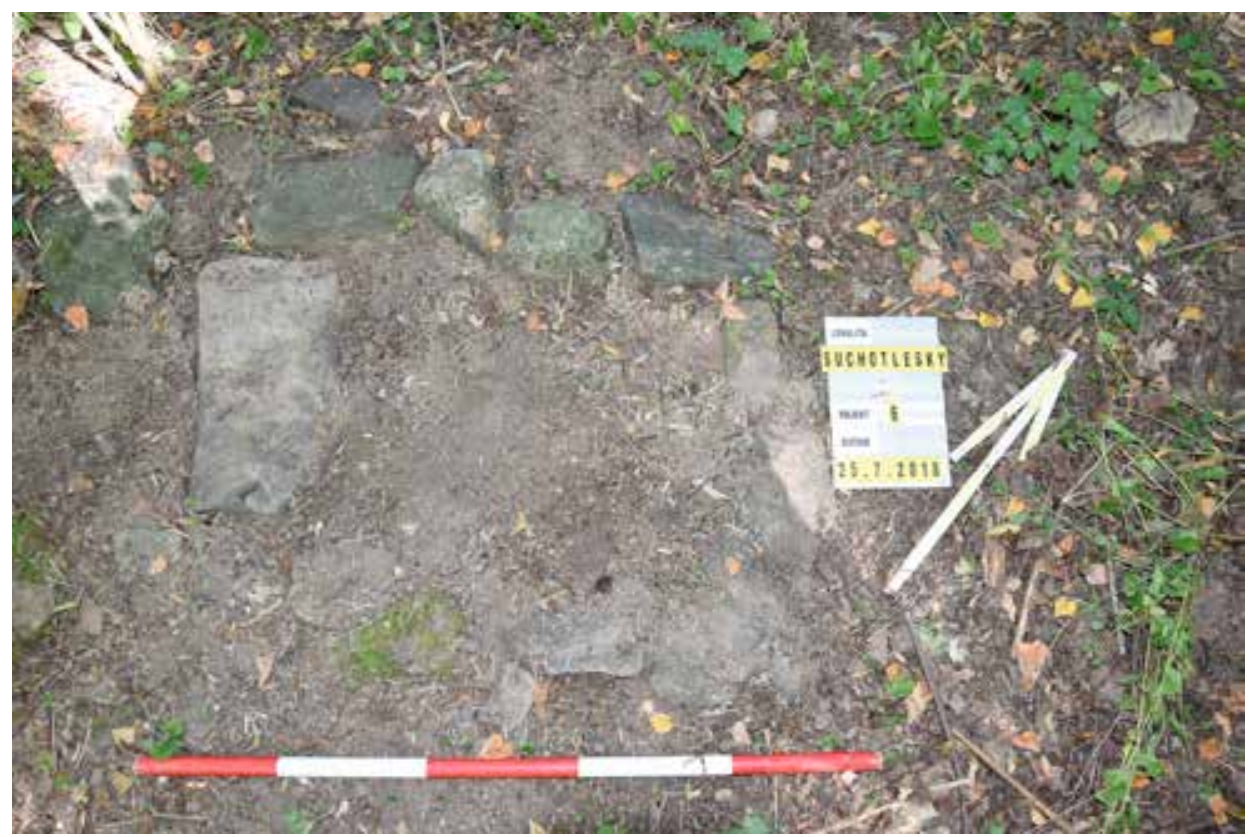

Obr. 7. Suchotlesky (k. ú. Ronov nad Doubravou). Detail dochované zděné konstrukce mlýna (obj. 6). Pohled od jihovýchodu. Stav v roce 2018. Foto J. Musil.

Abb. 7. Suchotlesky (Katastergebiet Ronov nad Doubravou). Detail der erhaltenen Mauerkonstruktion der Mühle (Obj. 6). Blick von Südosten. Zustand im Jahr 2018. Foto J. Musil. 
nalezneme pouze náznak obraného př́ikopu. Dispozičně je toto řešení relativně archaické, a navozuje hypotézu o starším původu tvrze.

Velmi důležité poznatky přinesl výzkum přímého hospodářského zázemí tvrze. Patrně v určitém odstupu od založení vlastní tvrze byla využita plocha nalézající se severně od tvrziště pro situování hospodářských objektů. Tuto plochu (obj. 4 - obr. 2:4, obr. 5) lze zřejmě ztotožnit s hospodářským dvorem zmiňovaným $v$ soupisu poddaných podle víry v roce 1651 (Zahradníková-Šreinová 1999, 406, 419). Na západní a východní straně takto vzniklé plochy byly nasypány zemní valy (obj. 8 a 9 - srov. obr. 2:8, 9, obr. 5), které zároveň plnily funkci hráze. Celý severozápadní prostor nad tvrzištěm byl zatopen rybníkem, na který navazovala kaskáda minimálně tří dalších nádrží. Není bez zajímavosti, že na mapě I. vojenského mapování i na tzv. císařském otisku mapy stabilního katastru z roku 1839 jsou již rybníky u tvrze vysušeny. Pouze na ploše louky v trati U Sádek se nalézá vodní nádrž, kterou rovněž na mapě I. vojenského mapování nenalezneme.

Severně od plochy hospodářského zázemí tvrze bylo registrováno torzo vodního náhonu (obj. 7 - obr. 2:7) pro mlýn na spodní vodu (obj. 6 - obr. 2:6, obr. 7). Hypoteticky se může jednat o jeden ze dvou mlýnů, které zmiňuje zakládací listina města Ronova nad Doubravou z roku 1307 (RBM IV, 824 č. 2124; srov. Štěpán-Šulc 2013, 122). Patrně nejmladší komponentu představují zbytky zahloubeného zděného objektu (obj. 5 - obr. 6), který částečně porušuje jižní konec obj. 8. Na základě písemných zpráv bychom ho mohli dát do souvislosti s hospodářským provozem v první polovině 18. století (Čermák 1882-1884, 238).

Po zaniklé vsi se dochovaly pouze nevýrazné stopy zaniklé plužiny registrované severně od reliktů mlýna (obj. 11 - obr. 2:11).

\section{Závěr}

Počátky tvrze a vsi Suchotlesky u Ronova nad Doubravou dostupné písemné prameny př́liš neosvětlují. První spolehlivé zmínky pocházejí až z 16. století. Nutno předeslat, že dispozice zdejší tvrze poukazuje na dřívější středověké založení. Navíc musíme předpokládat poměrně značnou transformaci zdejší sídelní sítě v rámci založení města Ronova nad Doubravou v roce 1307. Nedomníváme se, že by ke vzniku vsi Suchotlesky mohlo dojít až po tomto roce. Tvrz v Suchotleskách a její hospodářské zázemí se svým prostorovým uspořádáním odlišuje od ostatních známých tvrzí v železnohorském prostoru (např. Biskupice, Žleby, Stoupec, Zdislav-Komárka ad.). Dispozičně i vazbou na přilehlé hospodářské zázemí se blíží nejvíce tvrzišti Mrdice (k. ú. Heřmanův Městec). Ostatně s touto tvrzí ji nepřímo spojuje i zánik v období třicetileté války. ${ }^{3}$

Tato studie je dílčím výsledkem projektu Studentské grantové soutěže Západočeské univerzity v Plzni SGS-2018-049 „Hospodářské zázemí a přírodní prostředí zaniklých středověkých a novověkých vesnických sídel - 3. etapa“.

\section{Prameny a použitá literatura}

AČ III: Archiv český čili staré písemné památky české i morawské z archivůw domácích i cizích III (Palacký, F., ed.). Praha 1844.

AČ V: Archiv český čili staré písemné památky české i morawské z archivůw domácích i cizích V (Palacký, F., ed.). Praha 1862.

AČ VI: Archiv český čili staré písemné památky české i morawské z archivůw domácích i cizích VI (Palacký, F., ed.). Praha 1872.

3 V době odevzdání př́íspěvku do tisku byl terén tvrze, mlýna a hospodářského dvora výrazně narušen v souvislosti s nehlášenou parkovou úpravou. Některé části antropogenních reliktů byly nenávratným způsobem zničeny. Na pachatele byl podán podnět na zahájení správního řízení. Předložené zaměření tak tvoři významný doklad předchozí situace. 
AČ XXXI: Archiv český čili staré písemné památky české i moravské. První kniha provolací desk dvorských z let 1380 až 1394. Díl XXXI (Friedrich, G., ed.). Praha 1921.

AČ XXXII: Archiv český čili staré památky české i moravské XXXII (Čelakovský, J., ed.). Praha 1915.

AČ XXXIII: Archiv český čili staré památky české i moravské XXXIII (Čelakovský, J., ed.). Praha 1918.

BAIERL, P.-MUSIL, P.-NETOLICKÝ, P., 2015: Současný stav a obnova zříceniny hradu Rabštejnka (k. ú. Smrkový Týnec) - Gegenwärtiger Zustand und Restaurierung der Ruine von Burg Rabštejnek (Katastralgebiet Smrkový Týnec), AH 40, 23-51.

BÍLEK, T. V., 1883: Dějiny konfiskací v Čechách po roce 1618. Č́st druhá. Praha.

BIRNBAUMOVÁ, A.-JANSOVÁ, L., 1929: Soupis památek historických a uměleckých v politickém okresu Č́slavském. Praha.

CULEK, A., 1958: Drobné př́íspěvky k dějinám města Ronova n. Doubravou, Pardubický kraj II, 47-52.

ČERMÁK, K., 1874-1877: Současný přehled držitelů zboží v kraji Čáslavském dle register kontribuce z r. 1622, Památky archaeologické a místopisné X, 320-330.

- 1882-1884: Kde hledati jest Suchotlesky?, Památky archaeologické a místopisné XII, 238-239.

FROLÍK, J.-SIGL, J., 1995: Chrudimsko v raném středověku. Hradec Králové.

LÍVA, V., 1951: Prameny k dějinám třicetileté války. Regesta fondu Militare archivu ministerstva vnitra ČSR v Praze. Díl 3. Praha.

- 1953: Prameny k dějinám třicetileté války. Regesta fondu Militare archivu ministerstva vnitra ČSR v Praze. Díl 4. Praha.

MALINA, O., 2011: Stabilizace sídlení sítě vrcholného středověku ve střední a západní Evropě. Nepublikovaná disertační práce, ulož. na KAR FF ZČU, Plzeň.

- 2012: Samostatně stojící kostel jako doklad transformace osídlení - možnosti archeologie a GIS. In: Svorník 10, 33-44. Praha.

MUSIL, J., 2007: Neznámá zaniklá středověká vesnice pod Sečskou přehradou (k. ú. Seč a Hoješín, okr. Chrudim), Zpravodaj muzea v Hradci Králové 33, 199-219.

- 2011: Nové středověké a raně novověké nálezy z Trhové Kamenice (okr. Chrudim, Pardubický kraj), Východočeský sborník historický 19, 59-104.

- 2011a: Příspěvek archeologie k dějinám Trhové Kamenice, okr. Chrudim, ASČ 15, 969-988.

MUSIL, J.-NETOLICKÝ, P., 2012: Zaniklá středověká a raně novověká ves Bolešov v k. ú. Spačice, okres Chrudim, Pardubický kraj, Východočeský sborník historický 22, 73-114.

- 2013: Studium dynamiky středověkých sídelních struktur v tzv. bojanovském újezdu (Železné hory, okres Chrudim), REA - Živá archeologie 15, 32-37.

- 2014: Současný stav a perspektivy výzkumu antropogenních pozůstatků sídelních, výrobních a těžebních areálů v prostoru Železných hor, AVČ 5 (2013), 227-239.

- 2014a: Pozůstatky rýžování zlata v tzv. bojanovském újezdu (okres Chrudim) - Goldwäschereirelikte im sog. Bojanov-Sprengel (Bezirk Chrudim), AH 39, 637-655.

- 2014b: Tvrziště Stoupec a jeho hospodářské zázemí. Výsledky povrchového průzkumu na k. ú. Březinka u Hoštalovic (okr. Chrudim), AVČ 5 (2013), 148-180.

- 2014c: Dokumentace reliktů stř̌edověké těžby kovů v Železných horách, Živá archeologie - REA 16, 32-38.

- 2015: Výsledky povrchového průzkumu Železných hor v roce 2014, Výzkumy v Čechách 2014. Zprávy ČAS - Supplément 97, 52.

- 2015a: Rýžování zlata na Chrudimsku, Živá archeologie - REA 17, 60.

- 2015b: Dokumentace reliktů předhradí hradu Strádova (okres Chrudim) - Dokumentation der Relikte der Vorburg von der Burgruine Strádov (Bezirk Chrudim), AH 40, 457-473.

- 2016: Mezi vesnicí a vrchnostenským sídlem. Dvory na středověkém Chrudimsku - Zwischen Dorf und Herrschaftssitz. Mittelalterliche Höfe in der Region Chrudim, AH 41, 211-238.

- 2017: Nové archeologické nálezy z tzv. bojanovského újezdu (Železné hory, okres Chrudim). In: ...tenkrát na východě... Sborník k 80. narozeninám Víta Vokolka. Praehistorica XXXIII/1-2 (Popelka, M.-Šmidtová, R.-Burgert, P.-Jílek, J., edd.), 275-290. Praha.

- 2017a: Př́íspěvek k poznání polních opevňovacích objektů z roku 1968 na Chrudimsku - Feldbefestigungsobjekte aus dem Jahr 1968 in der Region Chrudim, AH 42, 579-593.

NOHEJLOVÁ-PRÁTOVÁ, E., 1957: Nálezy mincí v Čechách, na Moravě a ve Slezsku III. Praha.

ORTH, J.-SLÁDEK, F., 1870: Topograficko-statistický slovník Čech. Praha.

PEHAL, Z., 2003: Keramika 13. století od kostela svatého Kř́iže nedaleko Ronova nad Doubravou (okr. Chrudim), Chrudimský vlastivědný sborník 7, 3-17.

PROFOUS, A., 1951: Místní jména v Čechách. Jejich vznik, původní význam a změny. Díl III. M-̌̌̃. Praha. 
PROFOUS, A.-SVOBODA, J., 1957: Místní jména v Čechách. Jejich vznik, původní význam a změny. Díl IV. S-Ž. Praha.

RBM IV: Regesta diplomatica nec non epistolaria Bohemiae et Moraviae IV. (Emler, J., ed.). Praha 1892.

ROUBÍK, F., 1959: Soupis a mapa zaniklých osad v Čechách. Praha.

RT II: Reliquiae tabularum terrae regni bohemiae anno MDXLI igne consumptarum II. (Emler, J., ed.). Pragae 1872 .

SEDLÁČEK, A., 1900: Hrady, zámky a tvrze království Českého. Díl XII. Praha.

- 1909: Místopisný slovník historický království Českého. Praha.

SMETÁNKA, Z., 1977: Nálezová zpráva - povrchový průzkum ZSO Stusyně, k. o. Ronov nad Doubravou, ulož. v Archivu nálezových zpráv ARÚ AV ČR, Praha, v. v. i., TX197702257.

- 1987: Hledání zmizelého věku. Praha.

SMETÁNKA, Z.-ŠKABRADA, J., 1975: Nové poznatky o raně středověké architektuře na Čáslavsku, Umění XXIII, 262-266.

- 1977: K počátkům městečka Ronova nad Doubravou. In: Středověká archeologie a studium počátků měst (Richter, M., ed.), 105-112. Praha.

SOMER, T.-ŠRÁMEK, J., 2010: Historie benediktinského opatství sv. Petra a Pavla ve Vilémově (11601541). Praha.

SVOBODA, L. a kol., 2005: Encyklopedie českých tvrzí III (S-Ž). Praha.

SVOBODA, J.-ŠMILAUER, V., 1960: Místní jména v Čechách. Jejich vznik, původní význam a změny. Díl V. Dodatky k dílu Antonína Profouse. Praha.

ŠIMÁK, J. V., 1938: Středověká kolonisace v zemích Českých. České dějiny I/5. Praha.

ŠTĚPÁN, L.-ŠULC, I., 2013: Chrudimsko. Mlýny a další zařízení na vodní pohon. Chrudim.

ZAHRADNÍKOVÁ, M.-ŠREINOVÁ, E., 1999: Soupis poddaných podle víry z roku 1651. Čáslavsko 2. Praha.

\section{Zusammenfassung}

\section{Oberflächenuntersuchung des Siedlungs- und Wirtschaftskomplexes der Feste Suchotlesky (Katastergebiet Ronov nad Doubravou)}

Die Umgebung der Stadt Ronov nad Doubravou (Ronow an der Dobrawa) gehörte zusammen mit der majestätischen Burg Lichtenburg (Lichnice) zur einstigen historischen Region Č́alav. Heute gehört Ronov zum Verwaltungsbezirk Chrudim. Die relativ offene Landschaft des böhmischen Elblands ist hier leicht wellig und geht nach und nach in das Massiv des Eisengebirges über, das im Mittelalter eine natürliche Barriere darstellte. In der Umgebung der Stadt befinden sich zwei selbständig stehende romanische Kirchen, bei denen sich an einer ehemaligen Furt durch den Fluss Doubrava die mittelalterlichen Dorfwüstungen Protivany/Protivenice und Stusyně befanden. Beide Dörfer gingen der Entstehung von Ronov nad Doubravou voraus, das Ulrich von Lichtenburg im Jahr 1307 gründen ließ. Gerade an der Siedlung Protivany mit der Heilig-Kreuz-Kirche nimmt man die Existenz eines einstigen Marktfleckens an. Der Markt wurde dann zusammen mit dem Verwaltungszentrum der Pfarrei in das neugegründete Städtchen verlegt. Beide Siedlungen haben nach und nach an Bedeutung verloren, einen definitiven Punkt hinter ihre Existenz haben jedoch erst die Ereignisse des Dreißigjährigen Krieges gesetzt. Den Anfängen des Städtchens Ronov nad Doubravou und seinem Bezug zu den Dorfwüstungen Protivany/Protivenice und Stusyně wurde in der Vergangenheit eine beträchtliche Aufmerksamkeit entgegengebracht, besonders was die Transformation des mittelalterlichen Siedlungsnetzes betrifft.

Im südwestlichen Teil des Katasters der Stadt Ronov nad Doubravou befinden sich die ein wenig übergangenen Relikte der mittelalterlichen Dorfwüstung Suchotlesky. Der Komplex besteht aus der Dorfwüstung selbst und aus einem Herrensitz (einer Feste) mit angeschlossenem wirtschaftlichen Hinterland in Form eines Hofes, einer Mühle und mindestens drei Teichen.

Die Anfänge der Feste und des Dorfes Suchotlesky bei Ronov nad Doubravou, denen der vorliegende Beitrag gewidmet ist, wird von den verfügbaren schriftlichen Quellen nicht allzu sehr beleuchtet. Die ersten zuverlässigen Erwähnungen stammen erst aus dem 16. Jahrhundert. 
Es muss vorausgeschickt werden, dass die Anlage der einstigen Feste auf eine mittelalterliche Gründung hindeutet. Darüber hinaus müssen wir davon ausgehen, dass das dortige ehemalige Siedlungsnetz im Rahmen der im Jahre 1307 erfolgten Gründung von Ronov nad Doubravou beträchtlich transformiert wurde. Wir nehmen nicht an, dass es erst nach diesem Zeitpunkt zur Entstehung des Dorfes gekommen sein könnte.

Mithilfe einer zerstörungsfreien archäologischen Untersuchung wurden drei Konzentrationen von anthropogenen Relikten entdeckt. Die erste Konzentration wird von dem zentralen Kernbereich der Feste und einem Graben eingenommen und befindet sich an einem Felsenausläufer in einer Höhe von 251-250 m über dem Meeresspiegel. Die Feste selbst war an der Ostseite durch einen Steilhang und einen Wasserlauf geschützt, an der Westseite wurde sie durch ein Wasserreservoir und im Norden durch einen Graben und einen kleineren Wall gebildet. Die Befestigungsanlage konnte noch um einen turmartigen Bau mit quadratischem Grundriss ergänzt worden sein, der an der Furt durch den Fluss Doubrava gelegen war (Obj. 3). Von der Anlage her ist diese Lösung sehr archaisch und kann die Hypothese von einem älteren Ursprung der Feste aufkommen lassen.

Sehr wichtige Erkenntnisse lieferte die Untersuchung des direkten wirtschaftlichen Hinterlandes der Feste. Die nördlich von dem befestigten Platz gelegene Fläche wurde offensichtlich in einem gewissen zeitlichen Abstand von der Gründung der eigentlichen Feste für die Ansiedlung von Wirtschaftsobjekten genutzt. Diese Fläche (Obj. 4) kann offensichtlich mit dem Wirtschaftshof identifiziert werden, der in einem Untertanenverzeichnis nach dem Glauben aus dem Jahr 1651 Erwähnung findet. An der West- und Ostseite der so entstandenen Fläche wurden Erdwälle aufgeschüttet (Obj. 8 und 9), welche die Funktion eines Dammes erfüllten. Der gesamte nordwestliche Raum oberhalb des befestigten Platzes war von einem Teich überflutet, an welchen eine Kaskade und mindestens drei weitere Reservoirs anschlossen. Nicht uninteressant ist, dass die an der Feste gelegenen Teiche sowohl auf der Karte der ersten militärischen Kartierung, als auch auf dem sog. Kaiserlichen Abdruck der Karte des Stabilen Katasters aus dem Jahr 1839 bereits ausgetrocknet sind. Lediglich auf der Fläche der Wiese in der Lage U Sádek befindet sich ein Wasserreservoir, das man auf der Karte der ersten militärischen Kartierung ebenfalls nicht vorfindet.

Nördlich von der Fläche des wirtschaftlichen Hinterlandes der Feste wurde der Torso eines Mühlgrabens (Obj. 7) für ein unterschlächtiges Mühlrad (Obj. 6) registriert. Hypothetisch könnte es sich hier um eine der zwei Mühlen gehandelt haben, die in der Gründungsurkunde der Stadt Ronov nad Doubravou von 1307 aufgeführt werden. Die offenbar jüngste Komponente stellen Überreste eines eingetieften gemauerten Objektes dar (Obj. 5), welches das südliche Ende von Obj. 8 teilweise stört. Aufgrund von schriftlichen Erwähnungen könnte man es mit einem Wirtschaftsbetrieb in der ersten Hälfte des 18. Jahrhunderts in Verbindung bringen.

Von der Dorfwüstung sind nur undeutliche Spuren eines untergegangenen Flurstücks erhalten geblieben, das nördlich von dem Relikt der Mühle registriert wurde (Obj. 11).

Die vorliegende Studie ist Teilergebnis des Förderwettbewerbs für studentische Projekte der Westböhmischen Universität in Pilsen SGS-2018-049 „Das wirtschaftliche Hinterland und die Umwelt von mittelalterlichen und frühneuzeitlichen Dorfwüstungen - 3. Etappe“.

PhDr. Jan Musil, Regionální muzeum v Chrudimi, Široká 86, 53701 Chrudim, Katedra archeologie Filozofické fakulty Západočeské univerzity v Plzni, Sedláčkova 15, 30614 Plzeň, Česká republika, musil@muzeumcr.cz

Mgr. Petr Netolický, Katedra archeologie Filozofické fakulty Západočeské univerzity v Plzni, Sedláčkova 15, 30614 Plzeň, Česká republika,netolicky.petr@seznam.cz 
